\title{
ADSL, AMPD1, and ATIC Expression Levels in Muscle and Their Correlations with Muscle Inosine Monophosphate Content in Dapulian and Hybridized Pig Species
}

\author{
Rongsheng Zhu',2, Yanping Wang1,2, Huaizhong Wang1,2, Song Lin"1,2, Shouli Sun1,2, \\ Baohua Huang1,2, Hongmei Hu1,2* \\ ${ }^{1}$ Institute of Animal Science and Veterinary Medicine, Shandong Academy of Agricultural Sciences, Jinan, China \\ ${ }^{2}$ Shandong Key Laboratory of Animal Disease Control and Breeding, Jinan, China \\ Email: *huhongmeipatty@163.com
}

How to cite this paper: Zhu, R.S., Wang, Y.P., Wang, H.Z., Lin, S., Sun, S.L., Huang, B.H. and Hu, H.M. (2017) ADSL, AMPD1, and ATIC Expression Levels in Muscle and Their Correlations with Muscle Inosine Monophosphate Content in Dapulian and Hybridized Pig Species. Open Journal of Animal Sciences, 7, 393-404.

https://doi.org/10.4236/ojas.2017.74030

Received: July 16, 2017

Accepted: September 11, 2017

Published: September 14, 2017

Copyright $\odot 2017$ by authors and Scientific Research Publishing Inc. This work is licensed under the Creative Commons Attribution International License (CC BY 4.0).

http://creativecommons.org/licenses/by/4.0/

\begin{abstract}
We investigated the relationship between muscle inosine monophosphate (IMP) content and mRNA levels of ADSL, AMPD1, and ATIC in Dapulian $(\mathrm{DPL})$, Landrace $\times$ Dapulian $($ LDPL), and Duroc $\times$ Landrace $\times$ Dapulian (DLDPL) hybridized pigs. Methods: The total RNA in longissimus dorsi was isolated from Dapulian (DPL), Landrace $\times$ Dapulian (LDPL) and Duroc $\times$ Landrace $\times$ Dapulian (DLDPL) hybridized pigs, weighed about $95.0 \mathrm{~kg}, \mathrm{n}=$ 8/species. The internal genes with highest stability (YWHAZ and RPL4) were chosen from 11 common internal genes using Quantitative real-time PCR (qPCR) and geNorm software. The mRNA levels of ADSL, AMPD1 and ATIC genes were corrected with YWHAZ and RPL4 genes. The muscular IMP content was determined by HPLC. The muscular IMP content in DPL was higher than that in LDPL and DLDPL, 25.00\% ( $\mathrm{p}<0.05)$ and $15.56 \%(\mathrm{p}>0.05)$, respectively. The muscular mRNA level of ADSL gene in DPL and LDPL was higher than that in DLDPL, $24.14 \%$ and $12.07 \%$, respectively $(\mathrm{p}<0.05)$. The muscular mRNA level of ATIC gene in DPL and LDPL was higher than that in DLDPL, $66.67 \%$ and $33.33 \%$, respectively $(\mathrm{p}<0.05)$. The muscular mRNA level of AMPD1 gene in DPL and LDPL was higher than that in DLDPL, $14.49 \%$ and $33.26 \%$, respectively. Furthermore, the IMP content was positively correlated with the mRNA level of ADSL, AMPD1 and ATIC genes, respectively $(p<0.05)$. The mRNA level of ADSL gene was highly related to that of AMPD1 and ATIC gene, respectively $(\mathrm{p}<0.01)$, while that of AMPD1 gene was not strongly correlated with that of ATIC gene $(p>0.05)$. The muscular mRNA level of AMPD1, ADSL and ATIC genes and the muscular IMP content
\end{abstract}


in DPL were highest, followed by those in LDPL and DLDPL. The muscular IMP content was positively correlated with the muscular mRNA level of ADSL, AMPD1 and ATIC genes, respectively.

\section{Keywords}

Pigs, ADSL Gene, AMPD1 Gene, ATIC Gene, Correlation, Inosine Monophosphate

\section{Introduction}

Inosine monophosphate (IMP) is a key aroma component present in livestock and poultry muscle and an indicator of meat quality [1] [2]. The de novo synthesis of IMP in livestock and poultry requires a ten-step reaction, of which adenosuccinate lyase (ADSL) and 5-aminoimidazole-4-carboxamide ribonucleotide formyltransferase/IMP cyclohydrolase (ATIC) catalyze the last three steps [3] [4] [5] [6]. AMP deaminase 1 (AMPD1), which is highly expressed in muscle, catalyzes the hydrolysis of AMP into IMP and ammonia post-slaughter [7] [8]. Studies on IMP metabolism have mainly focused on the polymorphisms and mRNA levels of AMPD1, ADSL, and ATIC and their association with IMP content in chickens [7]-[16]. The study findings revealed that the expression levels of these genes are higher in muscle than in other tissues [7] [17] and that IMP content is associated with these three genes [5] [7] [10] [11] [14] [15]. The polymorphisms of ADSL, AMPD1, and ATIC in different swine species and their associations with IMP metabolism have been reported [4] [16] [18] [19] [20]. In porcine muscle, researchers have studied the factors that affect IMP content, including swine species and storage temperature post-slaughter [21] [22] [23]. However, no study has focused on the relationship between ADSL, AMPD1, and ATIC and IMP content. The correlation between mRNA levels of ADSL and IMP content has been reported [20], but not the correlation between mRNA levels of ATIC and AMPD1 and IMP content.

To determine the molecular mechanism of aroma component formation in native pigs and support the breeding of high-quality pigs, we measured the muscle mRNA levels of ADSL, AMPD1, and ATIC and determined their correlations with muscle IMP content in Dapulian (DPL), Landrace $\times$ Dapulian (LDPL), and Duroc $\times$ Landrace $\times$ Dapulian $($ DLDPL) hybridized pigs.

\section{Materials and Methods}

\subsection{Animals and Sampling}

All experimental procedures with animals were conducted in accordance with the standards specified by Administrative Committee for Laboratory Animals of the Institute of Animal Husbandry \& Veterinary Science, Shandong Academy of Agricultural Sciences (IACC20060101, 1 Jan, 2006). DPL, LDPL, and DLDPL hybridized pigs of similar parity $(\sim 25.0 \mathrm{~kg} ; \mathrm{n}=8$ per species $)$ were bred in 
Dongsan Dapulian Pig Seed Farm (Jining, Shandong, China). The animals had ad libitum access to water and feed and were sacrificed in Yinbao Food Co. Ltd. (Shandong, China), when the body weight was $\sim 95.0 \mathrm{~kg}$. Longissimus thoracis (6 g) was excised $30 \mathrm{~min}$ post-slaughter and stored in liquid nitrogen.

\subsection{Measurement of IMP Content}

Muscle IMP content was measured by HPLC [21] [23]. Briefly, $0.2 \mathrm{~g}$ of longissimus dorsi was ground in liquid nitrogen, dissolved in 5\% perchloric acid, and transferred into a volumetric flask. After $10 \mathrm{~min}, 10 \mathrm{~mL}$ of supernatant was transferred into another volumetric flask. The $\mathrm{pH}$ of the supernatant was adjusted to 6.5 with $0.5 \mathrm{~mol} / \mathrm{L} \mathrm{NaOH}$, and the volume was adjusted to $50 \mathrm{~mL}$ with distilled water. An aliquot $(1.5 \mathrm{~mL})$ of the solution was centrifuged at 15,000 $\mathrm{r} / \mathrm{min}$ for $10 \mathrm{~min}$ at $4^{\circ} \mathrm{C}$ (Eppendorf Centrifuge 5415R). The resulting supernatant was passed through a $0.45-\mu \mathrm{m}$ filter membrane (MILLEX GP) and analyzed by HPLC (Waters e2695 Separations Module, Waters 2489 UV/Visible Detector) coupled to a C18 column $(250 \times 4.6 \mathrm{~mm})$ and a UV detector set at $254 \mathrm{~nm}$.

\subsection{Total RNA Isolation and RT}

Total RNA was isolated from longissimus dorsi using RNAiso Plus reagents (TaKaRa) and subjected to $0.8 \%$ denaturing agarose gel electrophoresis. RNA content was measured using a NanoDrop 2000 spectrophotometer (Thermo Fisher Scientific). Residual DNA was removed, and cDNA was synthesized using a PrimeScript RT reagent kit (RR047A, Takara).

\subsection{Primer Design and Synthesis and Real-Time PCR}

Eleven genes (ACTB, GAPDH, B2M, TBP, RPL4, TOP2B, HMBS, HPRT1, SDHA, YWHAZ, and PPIA) were selected (Table 1) for stability analysis [24] [25] [26] [27]. The specific primers of ADSL, AMPD1, and ATIC were designed using Primer Premier 5.0 software (Table 2) and synthesized by Sangon Biotech Co. Ltd. (Shanghai, China).

Quantitative real-time PCR (qPCR) of cDNA was performed in triplicate using LightCycler ${ }^{\circledR} 480$ SYBR Green I Master (Roche). The reaction mixture (20 $\mu \mathrm{L})$ contained Blue-SYBR-Green mix $(10 \mu \mathrm{L}), 1 \mu \mathrm{L}$ of each forward and reverse primers $(10 \mu \mathrm{M} / \mu \mathrm{L}), \mathrm{cDNA}(1 \mu \mathrm{L})$, and distilled water $(7 \mu \mathrm{L})$. The PCR program consisted of a pre-denaturation step at $95^{\circ} \mathrm{C}$ for $5 \mathrm{~min}$, followed by 40 cycles at $95^{\circ} \mathrm{C}$ for $10 \mathrm{~s}$ (denaturation) and $60^{\circ} \mathrm{C}$ for $20 \mathrm{~s}$ (annealing and extension). The melting curve was performed at $95^{\circ} \mathrm{C}$ for $5 \mathrm{~s}$ (denaturation), $65^{\circ} \mathrm{C}$ for $60 \mathrm{~s}$ (annealing), and $97^{\circ} \mathrm{C}$ for $10 \mathrm{~s}$ (melting). The CT values of the internal genes and target genes were quantified using Roche LightCycler ${ }^{\circledR} 480$ (Roche).

\subsection{Statistical Analysis}

For the candidate internal gene, the minimal $\mathrm{Ct}$ value was set to 1 . The relative value of genes was calculated by $2^{-\Delta \mathrm{Ct}}$, where $\Delta \mathrm{Ct}=\mathrm{Ct}$ value of other samples - 
Table 1. Selected reference genes.

\begin{tabular}{|c|c|c|c|c|c|}
\hline Gene & Full name & Primer (5'-3') & $\begin{array}{l}\text { Length } \\
\text { (bp) }\end{array}$ & $\begin{array}{c}\text { GenBank } \\
\text { accession } \\
\text { number }\end{array}$ & Reference \\
\hline GAPDH & Glyceraldehyde-3-phosphate dehydrogenase & $\begin{array}{l}\text { F: TCGGAGTGAACGGATTTG } \\
\text { R: CCTGGAAGATGGTGATGG }\end{array}$ & 219 & AF017079 & $\begin{array}{l}\text { Martino et al. } \\
2011[25]\end{array}$ \\
\hline ACTB & Beta-actin & $\begin{array}{l}\text { F: TCTGGCACCACACCTTCT } \\
\text { R: GATCTGGGTCATCTTCTCAC }\end{array}$ & 114 & DQ178130 & $\begin{array}{l}\text { Martino et al. } \\
2011[25]\end{array}$ \\
\hline $\mathrm{B} 2 \mathrm{M}$ & Beta-2-microglobulin & $\begin{array}{l}\text { F: TTCACACCGCTCCAGTAG } \\
\text { R:CCAGATACATAGCAGTTCAGG }\end{array}$ & 166 & NM 213978 & $\begin{array}{l}\text { Martino et al. } \\
2011[25]\end{array}$ \\
\hline ТВP & TATA binding protein & $\begin{array}{l}\text { F: GATGGACGTTCGGTTTAGG } \\
\text { R: AGCAGCACAGTACGAGCAA }\end{array}$ & 124 & DQ178129 & $\begin{array}{l}\text { Martino et al. } \\
2011[25]\end{array}$ \\
\hline RPL4 & Ribosomal protein L4 & $\begin{array}{l}\text { F: AGGAGGCTGTTCTGCTTCTG } \\
\text { R: TCCAGGGATGTTTCTGAAGG }\end{array}$ & 185 & DQ845176 & $\begin{array}{l}\text { Cinar et al. } \\
2012[24]\end{array}$ \\
\hline PPIA & Peptidylprolyl isomerase A (cyclophilin A) & $\begin{array}{l}\text { F: CACAAACGGTTCCCAGTTTT } \\
\text { R: TGTCCACAGTCAGCAATGGT }\end{array}$ & 171 & NM_214353 & $\begin{array}{l}\text { Cinar et al. } \\
2012[24]\end{array}$ \\
\hline TOP2B & Topoisomerase II beta & $\begin{array}{l}\text { F: AACTGGATGATGCTAATGATGCT } \\
\text { R: TGGAAAAACTCCGTATCTGTCTC }\end{array}$ & 137 & AF222921 & $\begin{array}{l}\text { Martino et al. } \\
\text { (2011) [25] }\end{array}$ \\
\hline HMPS & Hydroxymethylbilane synthase & $\begin{array}{l}\text { F:CTGTTTACCAAGGAGCTGGAAC } \\
\text { R: TGAAGCCAGGAGGAAGCA }\end{array}$ & 100 & DQ178125 & $\begin{array}{l}\text { Tim et al. } \\
2006[27]\end{array}$ \\
\hline HPRT1 & Hypoxanthine phosphoribosyltransferase 1 & $\begin{array}{l}\text { F: CCGAGGATTTGGAAAAGGT } \\
\text { R: CTATTTCTGTTCAGTGCTTTGATGT }\end{array}$ & 181 & DQ178126 & $\begin{array}{l}\text { Martino et al. } \\
\text { (2011) [25] }\end{array}$ \\
\hline 40SDHA & Succinate dehydrogenase & $\begin{array}{l}\text { F: CTACAAGGGGCAGGTTCTGA } \\
\text { R:AAGACAACGAGGTCCCAGGAG }\end{array}$ & 141 & DQ845177 & $\begin{array}{c}\text { Nygard et al. } \\
2007[26]\end{array}$ \\
\hline YWHAZ & $\begin{array}{c}\text { Tyrosine 3-monooxygenase/tryptophan } \\
\text { 5-monooxygenase activation protein, zeta } \\
\text { polypeptide }\end{array}$ & $\begin{array}{l}\text { F: ATGCAACCAACACATCCTATC } \\
\text { R: GCATTATTAGCGTGCTGTCTT }\end{array}$ & 178 & DQ178130 & $\begin{array}{l}\text { Martino et al. } \\
\text { (2011) [25] }\end{array}$ \\
\hline
\end{tabular}

Table 2. Target genes.

\begin{tabular}{|c|c|c|c|c|}
\hline Gene & Full name & Primer $\left(5^{\prime}-3^{\prime}\right)$ & $\begin{array}{l}\text { Length } \\
\text { (bp) }\end{array}$ & $\begin{array}{c}\text { GenBank } \\
\text { Accession number }\end{array}$ \\
\hline ADSL & Adenylosuccinate lyase & $\begin{array}{l}\text { F: TATTGAGGTGCTCTCTGTGCTG } \\
\text { R: CTCTATCTCCTTGAGGTTTGCC }\end{array}$ & 156 & NM_001130733 \\
\hline ATIC & $\begin{array}{l}\text { 5-Aminoimidazole-4-carboxamide ribonucleotide } \\
\text { formyltransferase/IMP cyclohydrolase }\end{array}$ & $\begin{array}{l}\text { F: CAGGGGACAAGGCAAACTAT } \\
\text { R: TAACTCAGGGACCTCCTCAAAT }\end{array}$ & 182 & NM_001130736.1 \\
\hline AMPD1 & Adenosine monophosphate deaminase 1 & $\begin{array}{l}\text { F: GGTCTTTATCGGGCATTGTGT } \\
\text { R: AATACTTGGAAGCGGTTTTTGG }\end{array}$ & 82 & NM_001123076.1 \\
\hline
\end{tabular}

minimal Ct value. For stability analysis, data were analyzed using geNorm V3.5 software.

The relative expression of the target genes in DPL, LDPL, and DLDPL hybridized pigs was expressed as $2^{-\Delta \mathrm{Ct}}$, where $\Delta \mathrm{Ct}=\mathrm{Ct}$ value of the target gene $-\mathrm{Ct}$ value of internal gene. $\Delta \mathrm{Ct}>0$ is indicative that the level of the target gene is 
higher than that of the internal gene, while $\Delta \mathrm{Ct}<0$ is indicative that the level of the target gene is lower than that of the internal gene. Statistical analyses were performed with SPSS19.0 statistical software package for Windows (SPSS Inc., Chicago, IL, USA). Results were expressed as mean $\pm \mathrm{SD}$. One-way analysis of variance (ANOVA) was used for the comparison of muscle IMP content and expression of AMPD1, ADSL, ATIC between Dapulian and hybridized pig species.

\section{Results}

\subsection{Determination of RNA and qPCR Results}

We obtained three RNA bands (28S, 18S, and 5S) via agarose gel electrophoresis. The $\mathrm{A}_{260} / \mathrm{A}_{280}$ ratio and content of total RNA in muscle was $1.97 \pm 0.02$ and 268.9 $\pm 72.6 \mathrm{ng} / \mu \mathrm{L}$, respectively. For the target and internal genes, the amplification curve had a typical S-shape, the melting curve had a standard peak at $85^{\circ} \mathrm{C}$ $90^{\circ} \mathrm{C}$, and the amplification efficiency of the standard curve ranged from 0.95 to 1.1 , which met the requirements of relative quantitative analysis.

\subsection{Stability Analysis of Internal Genes}

The $\mathrm{Ct}$ values of the 11 internal genes in swine muscle $(\mathrm{n}=24)$ were measured using qPCR and analyzed using geNorm software. The stabilities of the internal genes were sorted according to the $\mathrm{M}$ values obtained from geNorm software (the smaller the $\mathrm{M}$ value, the higher the stability). The average stability degree of the two most stable internal genes was determined after successively removing the most unstable internal gene and analyzing the average of the stability degree of the remaining internal genes ( $M$ value). In decreasing order of $M$ value (Figure 1), the internal genes were SDHA $(0.770)>\mathrm{B} 2 \mathrm{M}(0.676)>$ PPIA $(0.582)>\operatorname{TBP}(0.556)>\operatorname{GAPDH}(0.489)>\operatorname{ACTB}(0.479)>\operatorname{HPRT1}(0.462)>$ TOP2B $(0.440)>$ HMBS $(0.438)>$ YWHAZ $(0.402)>$ RPL4 (0.390). Therefore, RPL4 had the highest stability, while SDHA had the lowest stability. Furthermore, the average $\mathrm{M}$ value of the 11 internal genes was 0.517 . After removing the $M$ value of the internal gene with the lowest stability, the average $M$ value of the remaining 10 internal genes was 0.460 . Successively, the average $M$ value of the two most stable internal genes (YWHAZ and RPL4) was 0.193 .

GeNorm software allows the determination of the number of internal genes by analyzing the matching variation, $\mathrm{V}$ value, and the selection of the optimal combination of internal genes other than a single internal gene. The $\mathrm{Vn} / \mathrm{Vn}+1$ ratio was compared with the default $\mathrm{V}$ value (0.15). At $\mathrm{Vn} / \mathrm{Vn}+1$ ratio $>0.15$, it is important to consider the $\mathrm{n}+1$ gene, whereas the new internal gene might not be considered. It would be optimal for the correction of system deviation to obtain more reliable results and analyze the subtle changes in gene expression. As shown in Figure 2, $\mathrm{V}_{2} / \mathrm{V}_{3}=0.094<0.15$, which revealed that the third internal gene might not be considered, and the average Ct value of YWHAZ and RPL4 may accurately correct and normalize the expression of the target gene. 


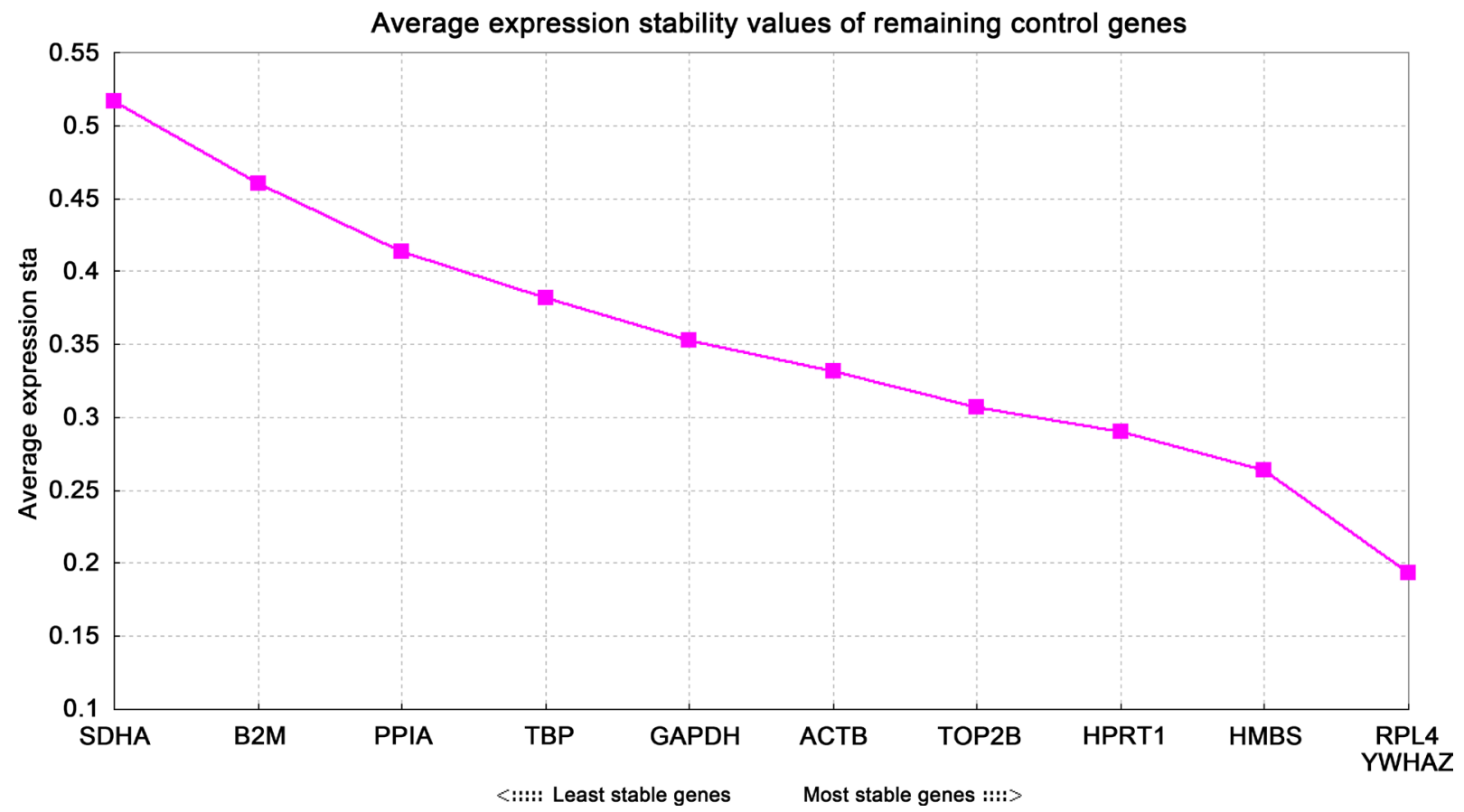

Figure 1. Average expression stability values of candidate reference genes.

Determination of the optimal number of control genes for normalization

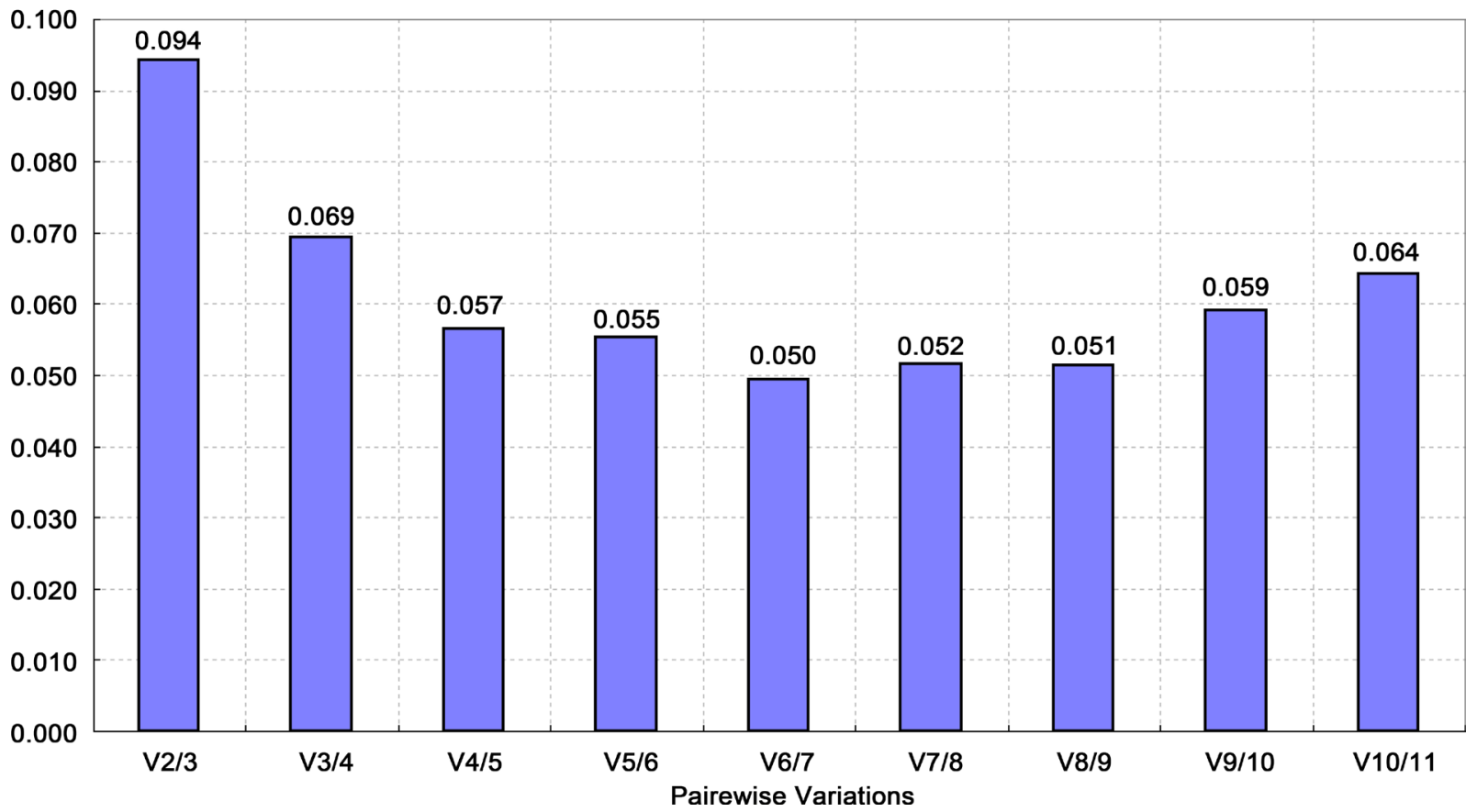

Figure 2. Determination of the optional number of candidate reference genes for normalization.

\subsection{IMP Content and Expression of Genes Involved in IMP Metabolism}

YWHAZ and RPL4 were selected as internal genes. The expression levels of ADSL, AMPD1, and ATIC were calculated by $2-\Delta \mathrm{Ct}$, where $\Delta \mathrm{Ct}=\mathrm{Ct}$ value of the target gene - Ct value of internal gene (Vandesompele, et al., 2002). As 
shown in Table 3, DPL had the highest IMP content in muscle, followed by LDPL and DLDPL. DPL had $25.00 \%(P<0.05)$ and $15.56 \%$ more IMP than DLDPL and LDPL, respectively, and LDLP had $8.17 \%$ more IMP than DLDPL $(P>0.05)$.

The muscle mRNA levels of $A D S L$ and $A T I C$ were higher in DPL and LDPL than in DLDPL, with no significant differences between DPL and LDPL. The mRNA levels of $A D S L$ were higher $(P<0.05)$ in DPL and LDPL than in DLDPL (24.14\% and $12.07 \%$, respectively). The mRNA levels of $A T I C$ were higher $(P<$ $0.05)$ in DPL and LDPL than in DLDPL (66.67\% and 33.33\%, respectively). The mRNA levels of $A M P D 1$ were higher in DPL than in LDPL and DLDPL (14.49\% and $33.26 \%$, respectively), while the difference between LDPL and DLDPL was not significant. Therefore, muscle IMP content in DPL, LDPL, and DLDPL had a similar trend to the mRNA levels of $A D S L, A M P D 1$, and $A T I C$.

\subsection{Correlation between IMP Content and mRNA Levels of Genes Involved in IMP Metabolism}

Table 4 shows that muscle IMP content was positively correlated with the mRNA levels of $A D S L, A M P D 1$, and $A T I C$ with correlation coefficients of 0.327 , 0.335 , and 0.342 , respectively $(P<0.05)$. The mRNA levels of $A D S L$ were positively correlated with the mRNA levels of $A M P D 1$ and $A T I C$ with correlation coefficients of 0.501 and 0.391 , respectively $(P<0.01)$. The mRNA levels of $A M P D 1$ were not significantly correlated with the mRNA levels of $A T I C$.

\section{Discussion}

Data correction with the appropriate internal gene is critical to obtain reliable

Table 3. IMP content and expression of ADSL, AMPD1, and ATIC.

\begin{tabular}{ccccccc}
\hline \multirow{2}{*}{ Index } & \multicolumn{2}{c}{ DPL } & \multicolumn{3}{c}{ LDPL } & \multicolumn{2}{c}{ DLDPL } \\
\cline { 2 - 7 } & Mean \pm SD & CV & Mean \pm SD & CV & Mean \pm SD & CV \\
\hline IMP (mg/g) & $2.60 \pm 0.32^{\mathrm{a}}$ & 8.26 & $2.25 \pm 0.22^{\mathrm{ab}}$ & 9.94 & $2.08 \pm 0.14^{\mathrm{a}}$ & 6.62 \\
ADSL & $0.72 \pm 0.04^{\mathrm{a}}$ & 6.02 & $0.65 \pm 0.05^{\mathrm{a}}$ & 6.35 & $0.58 \pm 0.06^{\mathrm{b}}$ & 9.66 \\
AMPD1 & $5.69 \pm 0.67^{\mathrm{a}}$ & 11.75 & $4.97 \pm 0.49^{\mathrm{b}}$ & 9.87 & $4.27 \pm 0.68^{\mathrm{b}}$ & 13.92 \\
ATIC & $0.05 \pm 0.01^{\mathrm{a}}$ & 13.45 & $0.04 \pm 0.00^{\mathrm{a}}$ & 9.15 & $0.03 \pm 0.00^{\mathrm{b}}$ & 8.84 \\
\hline
\end{tabular}

Different lowercase superscripts represent significant differences within the same row $(\mathrm{P}<0.05)$. DPL, Dapulian pig; LDPL, Landrace $\times$ Dapulian hybridized pigs; DLDPL, Duroc $\times$ Landrace $\times$ Dapulian hybridized pigs.

Table 4. Correlation between IMP content and expression of ADSL, AMPD1, and ATIC.

\begin{tabular}{cccc}
\hline Correlation coefficient & ADSL & AMPD1 & ATIC \\
\hline IMP & $0.327^{*}$ & $0.335^{*}$ & $0.342^{*}$ \\
ADSL & 1 & $0.501^{\star *}$ & $0.391^{* *}$ \\
AMPD1 & & 1 & 0.186 \\
\hline
\end{tabular}

${ }^{*} P<0.05 .{ }^{*} P<0.01$. 
data in mRNA expression analysis [28]. The expression of any internal gene cannot be consistent under different experimental conditions [26] [28] [29] [30] [31]. In this study, YWHAZ and RPL4 were selected as internal genes to correct the targets gene.

IMP, an indicator of meat quality, differs among porcine species. The IMP content of native pigs, including Laiwu and Yanan pigs, is significantly higher than that of lean species or native $\times$ hybridized pigs [21] [22] [23] [32]. In this study, muscle IMP content was the highest in DPL, followed by LDPL and DLDPL, which revealed that muscle IMP content decreased in the DPL bloodline. However, Zhang et al. [16] [20] reported that muscle IMP content was higher in Danish landrace than in thin Wei pig or Anqing six-white pig, which was not in agreement with other studies [21] [22] [23] [32]. This result might be attributed to slaughter age, dietary components, and feeding methods, which need further validation by increasing the sample size.

ADSL, AMPD1, and ATIC code for enzymes involved in IMP metabolism [3] [4] [5] [6] [7] [17]. Studies have reported that there are significant differences in muscle IMP content within the same chicken species due to point mutations in ADSL, AMPD1, or ATIC [5] [7] [9] [10] [14] [15]. The association between muscle IMP content and point mutations in ATIC or AMPD1 in swine [4] [18] [19] and the association between muscle IMP content and point mutations in ADSL in duck have been investigated, which can be used as a molecular marker for breeding strategies [33]. However, limited studies have focused on the relationship between IMP content and IMP-metabolic genes in chicken, duck, and swine or on the relationship between IMP content and AMPD1 in chicken, ADSL in duck, or ADSL in swine [16] [20] [33] [34]. No study has focused on the relationship between IMP content and ADSL, AMPD1, or ATIC in swine. In this study, the muscle mRNA levels of ADSL and ATIC were higher in DPL and LDPL than in DLDPL, while the mRNA levels of AMPD1 were significantly higher in DPL than in LDPL or DLDPL. Muscle IMP content had a similar trend to that of mRNA levels of ADSL, AMPD1, and ATIC. Muscle IMP content is affected by the expression of ATIC or AMPD1 in swine [4] [18] [19] and by the expression of ADSL, AMPD1, and ATIC in chicken [5] [7] [9] [10] [14] [15], consistent with our study findings. However, Zhang et al. [20] [34] reported that the expression of ADSL in Danish landrace was lower than that in Wei pig and higher than that in Anqing six-white pig without significant differences. Additionally, the expression of ADSL in Wei pig was higher than that in Anqing six-white pig, which was not consistent with our results. In this study, the muscle mRNA levels of ADSL were the highest in DPL, followed by LDPL and DLDPL. The different feeding methods between DPL and Wei and Anqing six-white pigs might affect the muscle IMP content and mRNA levels of ADSL resulting from. The muscle mRNA levels of AMPD1 in chickens and of ADSL in ducks are positively correlated with IMP content [33] [34], while the muscle mRNA levels of ADSL in swine are not highly correlated with IMP content [20] [34]. Our results showed that muscle IMP content was positively correlated with 
the mRNA levels of ADSL, AMPD1, and ATIC. The mRNA levels of ADSL were positively correlated with the mRNA levels of AMPD1 and ATIC, while the mRNA levels of AMPD1 were not significantly correlated with the mRNA levels of ATIC. The de novo synthesis of IMP consists of 10 reactions catalyzed by 10 enzymes. Muscle IMP can also be formed from the progressive hydrolysis of ATP post-slaughter, which involves several enzymes, such as ATPase, creatine kinase, adenosine deaminase, and phosphatase. Future studies should analyze the factors that affect muscle IMP content.

The relative expression of $A D S L$ in DPL, LDPL, and DLDPL was positively correlated with IMP content. IMP has medium heritability [35], which is important for the breeding of high-quality pigs. In this study, the mRNA levels of $A D S L, A M P D 1$, and $A T I C$ were different in the DPL hybridized pigs, which revealed that some key factors may regulate these genes. MicroRNA (miRNA) and siRNA are key molecules that regulate gene expression. MiRNAs are endogenous non-coding RNA molecules (22 nucleotides in length) with regulatory function in eukaryotes. MiRNAs recognize mRNA by base pairing and degrade the target mRNA or inhibit the translation of the target mRNA [36]. Specific miRNAs are involved in the regulation of $A D S L, A M P D 1$, and $A T I C$. If the correlation between the relative expression of other enzymes involved in IMP synthesis and the IMP content in the corresponding tissues is identified, the genes that code for those enzymes may represent suitable molecular markers that assist in the selection of animal species with high IMP content.

\section{Conclusion}

Muscle mRNA levels of $A D S L, A M P D 1$, and $A T I C$ and muscle IMP content were the highest in DPL followed by LDPL and DLDPL. Muscle IMP content was positively correlated with the mRNA levels of $A D S L, A M P D 1$, and $A T I C$.

\section{Acknowledgements}

This work was supported by the Youth Foundation of Shandong Academy of Agricultural Sciences [grant number 2014QNM41], the Key Research and Development Plan of Shandong Province, China [grant number 2015GNC111011], the National Natural Science Foundation of China [grant number 31501928, 31501927], and the Natural Science Foundation of Shandong Province, China [grant number ZR2015CM007].

\section{References}

[1] Zhang, G.Q., Ma, Q.G. and Ji, C. ( 2008) Effects of Dietary Inosinic Acid on Carcass Characteristics, Meat Quality, and Deposition of Inosinic Acid in Broilers. Poultry Science, 87, 1364-1369. https://doi.org/10.3382/ps.2007-00193

[2] Wifall, T.C., Faes, T.M., Taylor-Burds, C.C., et al. (2007) An Analysis of 5'-Inosine and 5'-Guanosine Monophosphate Taste in Rats. Chemical Senses, 32, 161-172. https://doi.org/10.1093/chemse/bj1043

[3] Boutchueng-Djidjou, M., Collard-Simard, G., Fortier, S., et al. (2015) The Last 
Enzyme of the de novo Purine Synthesis Pathway 5-Aminoimidazole-4-carboxamide Ribonucleotide Formyltransferase/IMP Cyclohydrolase (ATIC) Plays a Central Role in Insulin Signaling and the Golgi/Endosomes Protein Network. Mol Cell Proteomics, 14, 1079-1092. https://doi.org/10.1074/mcp.M114.047159

[4] Li, J.L., Li, H.T., Gao, L.F., et al. (2011) SNPs Site Analysis and Expression Characterization of ATIC Gene in Swine. Journal of Northeast Agricultural University, 42, 22-25.

[5] Ye, M.H., Chen, J.L., Zhao, G.P., et al. (2010) Correlation between Polymorphisms in ADSL and GARS-AIRS-GART Genes with Inosine 5'-Monophosphate (IMP) Contents in Beijing-You Chickens. British Poultry Science, 51, 609-613. https://doi.org/10.1080/00071668.2010.508486

[6] Zikanova, M., Skopova, V., Hnizda, A., Krijt, J., et al. (2010) Biochemical and Structural Analysis of 14 Mutant ADSL Enzyme Complexes and Correlation to Phenotypic Heterogeneity of Adenylosuccinate Lyase Deficiency. Human Mutation, 31, 445-455. https://doi.org/10.1002/humu.21212

[7] Chai, L.J., Chu, M.X., Wen, J., et al. (2005) Study on Polymorphisms of AMPD1 Gene and Its Association with IMP Content in Chickens. Acta Veterinaria et Zootechnica Sinica, 36, 1112-1120.

[8] Han, W., Zhang, X.Y., Li, H.F., et al. (2009) Effects of Single and Pyramiding Genotypes of ADSL and GARS-AIRS-GART Genes on Baier Chicken Muscle Inosine Monophosphate (IMP) Contents. Journal of Agricultural Biotechnology, 17, 577-581.

[9] Gong, L.L. (2011) Genetic Variation and Expression of ADSL and GARS-AIRS-GART Genes and Their Associations with Meat Quality in Chicken. Yangzhou University, Yangzhou.

[10] Hu, J., Yu, P., Ding, X., et al. (2015) Genetic Polymorphisms of the AMPD1 Gene and Their Correlations with IMP Contents in Fast Partridge and Lingshan Chickens. Gene, 574, 204-209. https://doi.org/10.1016/j.gene.2015.08.008

[11] Shu, J.T., Bao, W.B., Zhang, H.X., et al. (2007) Correlation between Adenylosuccinate Lyase (ADSL) Gene Polymorphism and Inosine Monophosphate Acid (IMP) Content in Domestic Fowl and Genetic Relationship between Red Jungle Fowl and Domestic Fowl. Hereditas, 29, 343-348. https://doi.org/10.1360/yc-007-0343

[12] Shu, J.T., Ji, W.L., Bao, W.B., et al. (2007) The Effect of ADSL and GARS-AIRS-GART Genes on Inosine Monophate Content in Chicken Meat. Acta Veterinaria et Zootechnica Sinica, 38, 786-791.

[13] Shu, J.T., Bao, W.B., Zhang, X.Y., et al. (2008) Association and Haplotype Analysis of purH Gene with Inosine Monophosphate Content in Chickens. Animal Biotechnology, 19, 310-314. https://doi.org/10.1080/10495390802391785

[14] Shu, J.T., Bao, W.B., Zhang, X.Y., et al. (2009) Combined Effect of Mutations in ADSL and GARS-AIRS-GART Genes on IMP Content in Chickens. British Poultry Science, 50, 680-686. https://doi.org/10.1080/00071660903391709

[15] Shu, J.T., Bao, W.B., Wu, X.S., et al. (2009) Analysis of the Polymorphisms of AIRC Gene and Its Genetic Effect on IM P Content in Chicken. Acta Veterinaria et Zootechnica Sinica, 40, 155-160.

[16] Zhang, H.F., Gao, G.L., Wang, H.W., et al. (2014) Effects of Different Breeds and Raising Modes on Meat Flavors and Candidate Genes Expression Levels. Journal of Agricultural Biotechnology, 22, 1018-1026.

[17] Morisaki, H. and Morisaki, T. (2008) AMPD Genes and Urate Metabolism. Nihon Rinsho, 66, 771-777. 
[18] Liu, H., Xu, Y., Zhao, L.L., et al. (2008) Molecular Cloning and Mutation Site Analysis of AMPD1 Gene in Swine. Yi Chuan, 30, 175-178. https://doi.org/10.3724/SP.J.1005.2008.00175

[19] Liu, H. (2008) Molecular Cloning, Expression and Genetic Variation of AMPD1 Gene in Wild Boar and Swine. Northeast Agricultural University, Haerbin.

[20] Zhang, X.D., Zhang, S.J., Ding, Y.Y., et al. (2015) Association between ADSL, GARS-AIRS-GART, DGAT1, and DECR1 Expression Levels and Pork Meat Quality Traits. Genetics and Molecular Research, 14, 14823-14830. https://doi.org/10.4238/2015.November.18.47

[21] Hu, H.M., Guo, J.F., Zhu, R.S., et al. (2011) Comparison of Inosinic Acid and Intramuscular Fat Content in Longissimus Muscles of Different Breed Pigs. Journal of Yangzhou University (Agricultural and Life Science Edition), 32, 34-36.

[22] Yao, Z.L., Liu, G.Q., Yan, W.M., et al. (2012) Changes and the Relationship of Inosine-5'-Monophosphate and Biogenic Amine of Chilled Pork during Storage. Science and Technology of Food Industry, 33, 184-191.

[23] Zhu, R.S., Hu, H.M., Han, H., et al. (2008) Research on Inosinic Acid and Intramuscular Fat Content in Musle of Laiwu Pigs. Acta Ecologiac Animalis Domastici, 29, 63-65.

[24] Cinar, M.U., Islam, M.A., Uddin, M.J., et al. (2012) Evaluation of Suitable Reference Genes for Gene Expression Studies in Porcine Alveolar Macrophages in Response to LPS and LTA. BMC Research Notes, 5, 107. https://doi.org/10.1186/1756-0500-5-107

[25] Martino, A., Cabiati, M., Campan, M., et al. (2011) Selection of Reference Genes for Normalization of Real-Time PCR Data in Minipig Heart Failure Model and Evaluation of TNF- $\alpha$ mRNA Expression. Journal of Biotechnology, 153, 92-99.

[26] Nygard, A.B., Jørgensen, C.B., Cirera, S., et al. (2007) Selection of Reference Genes for Gene Expression Studies in Pig Tissues using SYBR Green qPCR. BMC Molecular Biology, 8, 67. https://doi.org/10.1186/1471-2199-8-67

[27] Time, E., Mario, V.P., Jo, V., et al. (2006) Development of a New Set of Reference Genes for Normalization of Real-Time RT-PCR Data of Porcine Backfat and Longissimus Dorsi Muscle, and Evaluation with PPARGC1A. BMC Biotechnolgy, 6, 41-48. https://doi.org/10.1186/1472-6750-6-41

[28] Huggett, J., Dheda, K., Bustin, S., et al. (2005) Real-Time RT-PCR Normalisation: Strategies and Considerations. Genes and Immunity, 6, 279-284. https://doi.org/10.1038/sj.gene.6364190

[29] Chapman, J.R. and Waldenström, J. (2015) With Reference to Reference Genes: A Systematic Review of Endogenous Controls in Gene Expression Studies. PLoS ONE, 10, e0141853. https://doi.org/10.1371/journal.pone.0141853

[30] Dundas, J. and Ling, M. (2012) Reference Genes for Measuring mRNA Expression. Theory in Biosciences, 131, 215-223. https://doi.org/10.1007/s12064-012-0152-5

[31] Facci, M.R., Auray, G., Meurens, F., et al. (2011) Stability of Expression of Reference Genes in Porcine Peripheral Blood Mononuclear and Dendritic Cells. Veterinary Immunology and Immunopathology, 141, 11-15.

[32] Chen, Q.M., Zeng, Y.Q., Wei, S.D., et al. (2010) Study on Flavor Precursors, Nutritional and Eating Quality of Meat for Different Pig Breeds. Journal of Agriculture \& Life Sciences, 36, 299-305.

[33] Xu, S.J., Yu, D.B., Wang, F., et al. (2012) Analysis of Sequence Characters of ADSL Gene and Correlation between Gene Expression and IMP Content in Duck. Scientia Agricultura Sinica, 45, 774-785. 
[34] Zhang, S.J., Liu, L.Y., Yin, Z.J., et al. (2014) Comparison on IMP Content in Longissimus Dorsi Muscle in Pigs and Related Genes Expression. Food and Fermentation Industries, 40, 187-192.

[35] Chen, J.L., Zhao, G.P., Zheng, M.Q., et al. (2008) Estimation of Genetic Parameters for Contents of Intramuscular Fat and Inosine-5'-Monophosphate and Carcass Traits in Chinese Beijing-You Chickens. Poultry Science, 87, 1098-1104.

[36] Zheng, G.X.Y., Ravi, A., Calabrese, J.M., et al. (2011) A Latent Pro-Survival Function for the Mir-290-295 Cluster in Mouse Embryonic Stem Cells. PLOS Genetics, 7, e1002054. https://doi.org/10.1371/journal.pgen.1002054 